\title{
Correction to: Biologic Drug Quality Assurance to Optimize HER2+ Breast Cancer Treatment: Insights from Development of the Trastuzumab Biosimilar SB3
}

\author{
Diana Lüftner ${ }^{1} \cdot$ Gary H. Lyman ${ }^{2}$ · João Gonçalves ${ }^{3} \cdot$ Xavier Pivot $^{4} \cdot$ Minji Seo $^{5}$
}

Published online: 20 October 2020

(c) The Author(s) 2020

\section{Correction to: Targeted Oncology (2020) 15:467-475 https://doi.org/10.1007/s11523-020-00742-w}

The article Biologic Drug Quality Assurance to Optimize HER2+ Breast Cancer Treatment: Insights from Development of the Trastuzumab Biosimilar SB3, written by Diana Lüftner, Gary H. Lyman, João Gonçalves, Xavier Pivot \& Minji Seo, was originally published Online First without Open Access. After publication in volume 15, issue 4, pages 467-475 the author decided to opt for Open Choice and to make the article an Open Access publication. Therefore, the copyright of the article has been changed to $\odot$ The Author(s) 2020 and the article is licensed under a Creative Commons Attribution-Noncommercial 4.0 International License, which permits any non-commercial use, sharing, adaptation, distribution and reproduction in any medium or format, as long as you give appropriate credit to the original author(s) and the source, provide a link to the Creative Commons licence, and indicate if changes were made. The images or other third party material in this article are included in the article's Creative Commons licence, unless indicated otherwise in a credit line to the material. If material is not included in the

The original article can be found online at https://doi.org/10.1007/ s11523-020-00742-w.

Diana Lüftner

diana.lueftner@charite.de

1 Department of Hematology, Oncology and Tumor Immunology, Charité Campus Benjamin Franklin, Charité University Medicine Berlin, Hindenburgdamm 30, 12200 Berlin, Germany

2 Fred Hutchinson Cancer Research Center, Seattle, WA, USA

3 iMed, Faculdade Farmacia da Universidade Lisboa, Lisbon, Portugal

4 Centre Paul Strauss, Strasbourg, France

5 Samsung Bioepis Co., Ltd., Incheon, Republic of Korea article's Creative Commons licence and your intended use is not permitted by statutory regulation or exceeds the permitted use, you will need to obtain permission directly from the copyright holder. To view a copy of this licence, visit https ://creativecommons.org/licenses/by-nc/4.0/.

The original article has been corrected.

Open Access This article is licensed under a Creative Commons Attribution-NonCommercial 4.0 International License, which permits any non-commercial use, sharing, adaptation, distribution and reproduction in any medium or format, as long as you give appropriate credit to the original author(s) and the source, provide a link to the Creative Commons licence, and indicate if changes were made. The images or other third party material in this article are included in the article's Creative Commons licence, unless indicated otherwise in a credit line to the material. If material is not included in the article's Creative Commons licence and your intended use is not permitted by statutory regulation or exceeds the permitted use, you will need to obtain permission directly from the copyright holder. To view a copy of this licence, visit https://creativecommons.org/licenses/ by-nc/4.0/. 